\title{
Strategy for Kleder Competency Improvement in The Camara Nusantara Cattle Ship
}

\author{
Strategi Peningkatan Kompetensi Kleder di Kapal Ternak Camara Nusantara
}

\author{
A. M. Fuah ${ }^{1}$, Zulhijariyanto ${ }^{1 *}$, L. Cyrilla ${ }^{1}$, Y. Triyonggo ${ }^{2}$, \& Z. Assegaf ${ }^{3}$ \\ ${ }^{1}$ Department of Animal Production Technology, Faculty of Animal Science, IPB University, Bogor, 16680 \\ ${ }^{2}$ PT Bridgestone Tire Indonesia, Bekasi, 17124 \\ ${ }^{3}$ Indonesian Livestock Logistics Forum, Bogor, 16680 \\ *Corresponding author: riyan.zul@gmail.com \\ (Received 22-06-2020; Revised 12-08-2020; Accepted 08-09-2020)
}

\begin{abstract}
Camara Nusantara ship was provided for livestock transportation especially cattle, to help increasing efficiency and decrease weight losses in the supply chain process. There were, however, such poor cattle performance was still found on the arrival port, which was claimed as related to the poor management and less competence of working personnel on board, one of those was kleder. This study was aimed at analyzing the strategy for increasing Human Resource competency in the Camara Nusantara Livestock Ship. Method used in this study was observations on target location, documentation, literature review, and depth interviews with target respondents in the respective locations, qualitative analysis approach was applied for data analysis. Analytical Hierarchy Process (AHP) with five levels were used to analyze data obtained from the study. The results indicate that the main strategies for increasing the competency of human resource in the Camara Nusantara Livestock Ship was started with development of competency standardization with a weight of $\mathbf{0 . 3 6 1}$. Development of competency standards for kleder is required to provide a guidelines for improving kleder's skills and knowledge in managing and handling livestock at Camara Nusantara Livestock Ship. It can be concluded that to optimize kleder competency who are working at Camara Nusantara Cattle Ship may help to maintain cattle performance during the sea toll transportation. Therefore, developing a national job competency standard, so called SKKNI (Standar Kompetensi Kerja Nasional Indonesia) is needed as guidance to formulate relevant training programs for human resource development.
\end{abstract}

Keywords: AHP, cattle ship, competency, Kleder, transportation

\begin{abstract}
ABSTRAK
Kapal Camara Nusantara dibuat untuk transportasi ternak khususnya sapi, untuk membantu meningkatkan efisiensi dan mengurangi kpenurunan bobot badan dalam proses rantai pasok. Namun demikian, performa sapi yang kurang baik masih ditemukan di pelabuhan kedatangan, yang diklaim berkaitan dengan manajemen yang buruk dan kompetensi tenaga kerja yang kurang, salah satunya adalah kleder. Penelitian ini bertujuan untuk menganalisis strategi peningkatan kompetensi Sumber Daya Manusia Kapal Ternak Camara Nusantara. Metode yang digunakan dalam penelitian ini adalah observasi di lokasi sasaran, dokumentasi, studi pustaka, dan wawancara mendalam dengan responden sasaran di masing-masing lokasi, pendekatan analisis kualitatif digunakan untuk analisis data. Analytical Hierarchy Process (AHP) dengan lima level digunakan untuk menganalisis data yang diperoleh dari penelitian. Hasil penelitian menunjukkan bahwa strategi utama peningkatan kompetensi sumber daya manusia Kapal Ternak Camara Nusantara diawali dengan pengembangan standardisasi kompetensi dengan bobot 0,361. Pengembangan standar kompetensi kleder diperlukan untuk memberikan pedoman peningkatan keterampilan dan pengetahuan kleder dalam mengelola dan menangani ternak di Kapal Ternak Camara Nusantara. Hal tersebut dapat disimpulkan bahwa dengan mengoptimalkan kompetensi kleder yang bekerja di Kapal Ternak Camara Nusantara dapat membantu dalam menjaga performa ternak selama transportasi tol laut. Oleh karena itu, pengembangan standar kompetensi kerja nasional yang disebut SKKNI (Standar Kompetensi Kerja Nasional Indonesia) diperlukan sebagai pedoman untuk merumuskan program pelatihan yang relevan untuk pengembangan sumber daya manusia.
\end{abstract}

Kata kunci: AHP, Kapal Ternak, Kompetensi, Kleder, Transportasi 


\section{INTRODUCTION}

The Indonesia government seeks to support the distribution of livestock in Indonesia by implementing the sea toll program. Inter island livestock transportation facilities in Indonesia were mostly using trucks or trains and sea transportation using cargo ships (Ilham and Yusdja 2017). The sea toll program was supported by Government through national policy and decree (Regulation of The President of The Republic Indonesia Number 106 of 2015 about Organization of Public Service Liabilities for Sea Transport) in order to strengthen and improve the logistic system on livestock in Indonesia. The Camara Nusantara Livestock Cattle Ship was provided by Government to improve the efficiency of cattle distribution to Jakarta, from several regions such as west and eastern part of Nusa Tenggara and South Sulawesi (Direktorat Jenderal Peternakan dan Kesehatan Hewan 2017). Haryana and Nuryati (2016) reported that the mechanism of livestock transportation using Camara Nusantara Cattle Ship was more effective than conventional transportation systems. Costs and time efficiency including human resources were significant and weight loss of cattle at the arrival port was low.

Comparison on transportation mechanisms between Camara Nusantara Cattle Ship and conventional transportation showed that transportation by Camara Nusantara Cattle Ship shortens the travel time from one and a half months to one week, decreasing costs from IDR $1,500,000$ to IDR 1,100,000 reduced weight loss for livestock ( $22 \%$ to $5 \%$ ) and cut supply chains from 13 points to 4 points (Haryana and Nuryati 2016). However, the role of Human Resources in the Camara Nusantara Cattle Ship especially kleder, has not been optimized. Kleder is cattle workers who are in charge with cattle management in the Indonesia cattle ship during transportation, had an important roles dealing directly with livestock management on board. It was designed to increase efficiency, maintaining performance by considering animal welfare so that decrease weight losses from $20 \%$ to only $8-10 \%$. It will be resulted in avoiding farmers from financial lose (Jurnal Maritim 2019).

Data from several sources revealed that during transportation, cattle weight losses was decreased from $20 \%$ to approximately 2-5\% (Haryana and Nuryati 2016); 8-10\% by Jurnal Maritim (2019), while death cases was not reported. These problems were mainly caused by low quality feed and less its availability including feeding management during transportation, handling practices without considering animal welfare, and poor waste management. The quality of environmental air and crate surroundings would have effects on cattle performace and welfare (Talithania et al. 2020). All of these were closely related to the skills, working performance and responsibility of crews or kleder on the ship. Observation on feeding management by kleder during the trip revealed that the type of feed provided for the cattle were only rice straw in low quality, given twice/day which was much lesser then the required amount of approximately $10 \%$ of the individual cattle body weight. Management and handling of cattle during transportation was relatively poor and did meet the common standard including feeding and drinking system, health and waste management. According to Talithania et al. (2020), low environmental condition Despite the great number of kleders were applied, the competency and skills of kleders were very low indicated by such a low education background, skills and the ways of handling animal during transportation which was just based on experience (Zulhijariyanto et al. 2019). The problem of Human Resources working on Camara Nusantara Livestock Ships has not been addressed yet, especially concerning the recruitment and criteria needed for kleders who are responsible for cattle handling during the trip (Winarso 2017). Limitation of necessary facilities and technology available on the ship might also be responsible to the low logistic efficiency of cattle transportation. For example, the capacity of the Cattle Ship was 500 cows with the numbers of crews of 30 personnel's, while the MV Ocean Ute could carry \pm 4000 cows handled by 36 crews (Wellard 2018). This indicate that in Camara Nusantara Cattle Ship, one crew could manage 15 cattle, whereas in MV Ocean Ute Ship of Australia one crew could manage 111 cattle. The absence of a work description and guideline for safety of the kleder resulted in poor management and misconduct of animal handling on board, including safety risk of the kleder. According to Hermsworth and Coleman (2014), lack of awareness to the importance of the roles of kleder had significant impact on livestock performance and welfare, during transportation.

This study aimed to analyze and formulate strategies for kleder competence development who are working in Camara Nusantara Cattle Ship, in order to improve cattle performance and value chain efficiency during transportation.

\section{MATERIALS AND METHODS}

This research was conducted for 6 months from November to December 2018 consisted of preparation, site and respondent selection, data collection and analysis. The locations was at Tanjung Priok Port, Kupang Livestock Ship Harbor, KM Camara Nusantara Ship, and Faculty of Animal Husbandry, Bogor Agricultural University. Data collection was carried out for one month by observation to the respective locations as suggested by Arikunto (2006), that observation method was used to collect data or information directly from the selected target location. Criteria for selecting experts as respondent in this study was based on educational background and experiences of experts in the areas of logistics and extensive knowledge on livestock transportation. There werre 5 experts chosen for interview from different fields and institutions including Human Resource management (1 person), academics staff from animal husbandry ( 2 people), breeders ( 1 person), and government ( 1 person). Beside interview, all experts were also asked to fill up questionnaires which were prepared before hands.

All data were descriptively analysed, arranged in Tables and Figures. Based on all important elements on Human Resource Development (HRD), the Analytical 
Hierarchy Process (AHP) was used to formulate strategies issues needed to improve the comptency of HRD. The AHP was used to determine the most suitable strategy to improve the competency of the competitor in the Camara Nusantara Livestock Ship. According to Saaty (1991), AHP was a data management by organizing all information and opinions of experts to build desired ideas / alternatives. The first steps of AHP was to determine the problems; the second, to design a hierarchical structure consisting of the main objectives and criteria; the third, to performs a paired matrix test between elements in all criteria; and the last to conclude the results from a paired matrix test. According to Hafeez and Essmail (2007), tolerance to deviations measured by the consistency ratio (CR) in AHP was that the should be inconsistency below $10 \%$. CR is a measure to check the consistency of judgments made by experts. CR is used in the AHP approach to improve the accuracy of the data collected.

The elements observed were presented in Figure 1. Detail description are as follows: Factors consisting of Human Resources (HR), facilities and infrastructure, work environment and ship management. Actors consisting of livestock owners, kleders, ship operators, government, transporter services, and livestock buyers. The Objectives consisted of increasing knowledge, improving the performance of the farmer, maintaining the quality of the product (livestock), and increasing the standard of the worker kleder. Strategies consisting of competency-based training and development, increasing work motivation and incentives (reward), developing competency standards, and improving the recruitment system.

\section{RESULTS AND DISCUSSION}

Based on the results, strategies to improve kleder competency on Camara Nusantara Cattle Ship taking into account every related elements with the value consistency ratio (CR) obtained was less than 10\%. Al-Harbi (2001) stated that $\mathrm{CR}$ values less than $10 \%$ indicating a consistent data and fair assessment. The result seen in Table 1 revealed that the consistency ratio (CR) was 0.01 could be accepted.

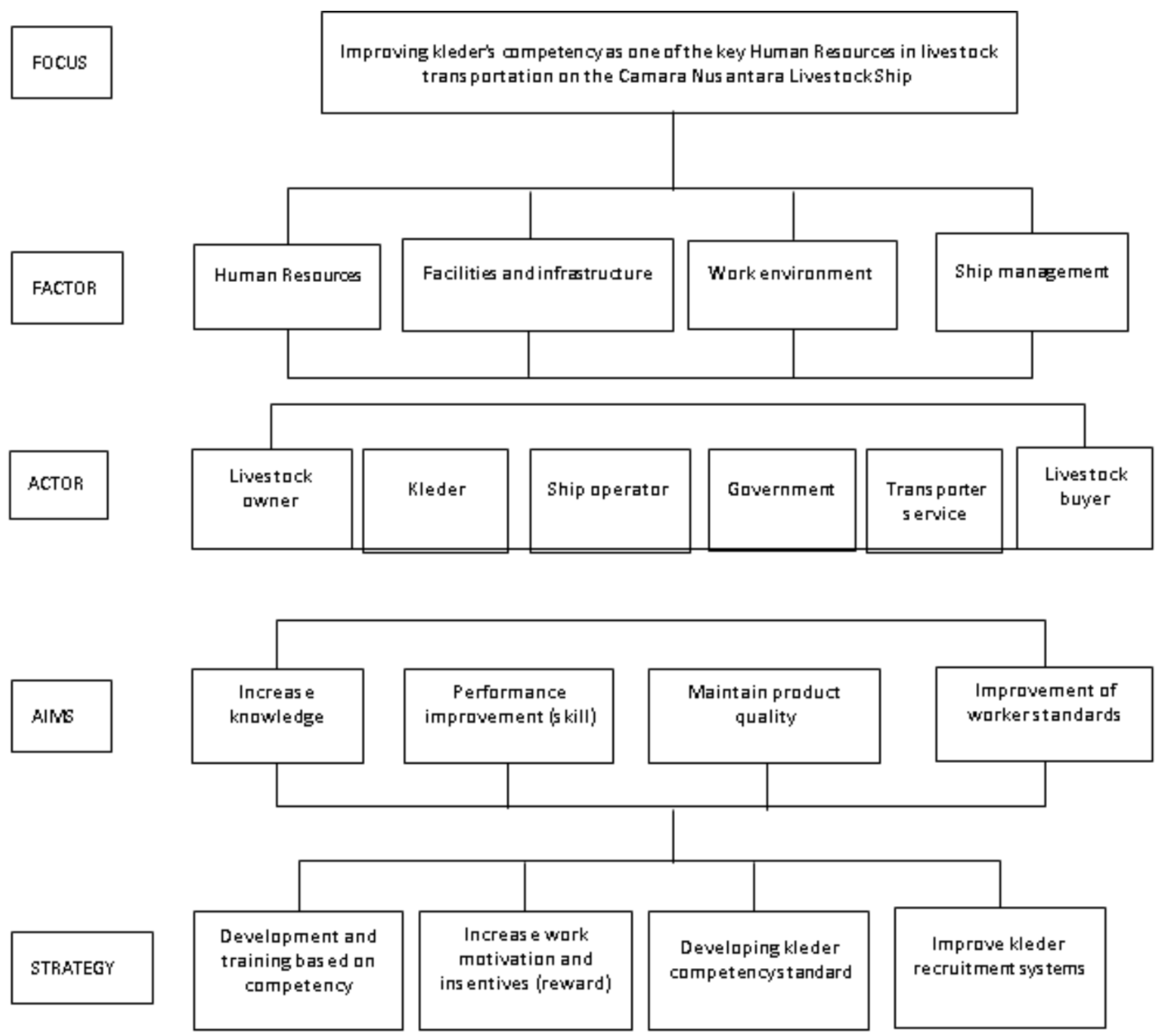

Figure 1. The Hierarchy Structure of the Kleder Competency Improvement in KM Camara Nusantara 
Table 1. Strategies for Improving the Kleder competency based on priority factors in the Camara Nusantara Cattle Ship

\begin{tabular}{lcc}
\hline Factor elemen & Weight & Priority \\
\hline Human Resources (HR) & 0.456 & 1 \\
Facilities and infrastructure & 0.253 & 2 \\
Work environment & 0.165 & 3 \\
Ship management & 0.127 & 4 \\
\hline
\end{tabular}

It was revealed that there were 4 (four) main strategies; one of which the necessity to improve kleder competency on Camara Nusantara Cattle Ship. On th Factor level, the highest influence evel of kleder competency improvement, was at Human Resource with high value of 0.456 , compared to the other elements such as ship management, facilities and infrastructure, and the work environment.

Human Resources was an essential Factor in the organization which would be functioning as an important factor to facilitate all operational activities for improving cattle performance. Kleder's competency improvement was the key factor determining the whole operation of livestock management including the utilization of all facilities and waste management activities on board. This was in accordance with the conditions on the livestock vessels, the carryng capacity, crate density and facilities available. This was consistent with Hermsworth and Coleman (2014), which stated that the kleder is the most influential factor affecting animal handling, welfare and productivity.

According to Matutina (2001) and Ardiana et al. (2010), the quality of personnel in an organization affected by knowledge, skill, and working capabilities. The way to manage livestock, influencing the cattle performance both productivity and other aspects such as animal welfare during the transportation process. Hermsworth and Coleman (2011) stated placement of personnel for animal handling was necessary in maintaining the performance and welfare of animals.

According to Schipp (2013), based on Australian Standard of Export of the Livestock (ASEL) every voyage had at least one accredited livestock officers, with or without an certified veterinarian. The second priority was ship management with a value of 0.253 was important in facilitating all management once the animals were on board. For example, the availability of water and feed in sufficient quantity to meet the animal requirement would help to maintain the animal condition during transportation. The third priority was facilities and infrastructure with a value of 0.165 . Boat operators provided all necessary facilities and infrastructure to support the operational management of livestock during the trip including feeding, drinking, health and waste management on board. The performance and condition of the livestock depending significantly on the feeding and drinking system availability and practices implement on the ship.

This study revealed that the type of feed given to the cattle during the transportation consisted only rice straw with relatively low digestibility $(30 \%)$, reported by
Sudarwati and Susilawati 2013) and low crude protein (3\%5\%, Yanuartono et al. 2017). Improper feed storage in the ship affected the feed quality which influencing the total nutrient consumption. In addition, the type of feed given should consider the eating behaviour of animal during transportation as well as the kleder roles in handling the animals appropriately during feeding time.

The results of the actor level weight analysis can be seen in Table 2. The results on the actor level indicate that the ship operator was the most influential actor responsible to increase kleder competency with the value 0.254 . The ship operator had full responsibility for the operation of the ship during the trip, including arranging the work of the kleder, improve the operational skill of kleders so that the workers are fully trained in handling of livestock. This is consistent with the statement of Bergenhenegouwen et al. (1996), that related company was responsible for developing the

Table 2. Strategies for Improving the Kleder competency based on actors in the Camara Nusantara Cattle Ship

\begin{tabular}{lcc}
\hline Actor elemen & Weight & Priority \\
\hline Ship operator & 0.245 & 1 \\
Goverment & 0.224 & 2 \\
Kleder & 0.138 & 3 \\
Livestock owner & 0.134 & 4 \\
Livestock buyer & 0.133 & 5 \\
Transporter service & 0.129 & 6 \\
\hline
\end{tabular}

competence of its employees in the company's operations. In fact, kleders as one of the Human Resources on board, was not recruited by PT PELNI as a ship operator, because PT PELNI does not have the authority to do so. It is therefore, the task to improve kleder's skills was not the responsibility of the organisastion. DAFF (2011) reported that ship operators must ensure certification of kleders as crew members. This scheme has been carried out in Australia, the on board stock person (kleder) on the ship must be certified before shipping to carry out good handling practices for livestock. Ship operators was just responsible to provide and develop the facilities required by the commander to carry out their task.

Based on the Minister of Transportation (2016), the ship operator's role in the operation of cattle ships by the government is PT Pelayaran Nasional Indonesia. Albayrak and Erensal (2004) stated that the physical workplace strongly influences human performance, both workplace factors affect the body and mind. DAFF has regulation for workplace standards for kleders on board during livestock transportation stated in the 2011 Australian Standard of Export of the Livestock (ASEL). These factors also have a direct impact on other elements that constitute a work environment with a value 0.165 , and factors ship management with that value 0.127 .

The result in Table 3 revealed that based on "goals" to be achieved, to increase the standard of workers (kleder) was the priority strategy. The second priority was maintaining the quality of product (livestock), followed by improving skill and knowledge. The educational background of the current 
Table 3. Strategies for Improving the Kleder competency based on Goal to be Achieved in the Camara Nusantara Cattle Ship

\begin{tabular}{lcc}
\hline Goal elemen & Weight & Priority \\
\hline $\begin{array}{l}\text { Improvement of kleder work } \\
\text { standards }\end{array}$ & 0.280 & 1 \\
$\begin{array}{l}\text { Maintain product quality } \\
\text { (livestock animal) }\end{array}$ & 0.271 & 2 \\
$\begin{array}{l}\text { Performance improvement (skill) } \\
\text { Increase knowledge }\end{array}$ & 0.237 & 3 \\
\hline
\end{tabular}

kleder were mostly junior high school or elementary school graduates with no training in handling cattle on board, and working by experience with less knowledge. Ananda et al. (2016) stated that competency-based training was needed by following the curriculum prepared by the government (Ministry of Manpower). This issue has been discussed in most of animal husbandry institutions, and other meetings held by Indonesian Livestock Logistics Forum (FLPI) on how the importance of livestock transportation and logistics in Indonesia.

According to SKKNI document (Indonesian National Work Competency Standard), standard competencies needed for kleders during the trip according to ASEL (DAFF 2008), were including handling animals during quarantine, the process of loading and unloading at the quarantine center, maintaining and feeding the cattle during quarantine and shipping, recording livestock, maintaining conditions of the cattle sheds on ships livestock, feed storage management, proper animal handling practices, and implementing animal health care during travel.

Alternative strategies suggested to improve the kleder competency standard were presented in Table 4. Kleder had a crucial roles in animal transportation on Camara Nusantara Ship especially to maintain and keep all livestock under good management, including feeding, health, animal welfare and other conditions that comply with animal welfare regulations. SKKNI is, therefore, very important and need to be provided as competency standards and fundamental guidelines for the implementation of work for kleders on Camara Nusantara Livestock Ships. Palermo et al. (2016) stated that competence standards that containing the description knowledge, skills, and attitudes required by workers were essential to be included in curriculum and assessment guidelines for education

Table 4. Alternative Strategies for Improving the Kleder competency in the Camara Nusantara Cattle Ship

\begin{tabular}{lcc}
\hline Alternative elemen & Weight & Priority \\
\hline $\begin{array}{l}\text { Developing kleder competency } \\
\text { standard }\end{array}$ & 0.361 & 1 \\
$\begin{array}{l}\text { Development and training based on } \\
\text { competency }\end{array}$ & 0.255 & 2 \\
$\begin{array}{l}\text { Increase work motivation and } \\
\text { incentives (reward) }\end{array}$ & 0.194 & 3 \\
$\begin{array}{l}\text { Improve kleder recruitment systems } \\
\text { Impro }\end{array}$ & 0.190 & 4 \\
\hline
\end{tabular}

purposes and preparation of professionals. Second strategy was focused on Human Resource development in order to produce kleders with appropriate skills required through competency-based trainings.

The work competence standard would be a guideline containing the framework that must be carried out by the kleder while working on a cattle ship, which in line with the statement of Jolly (2012) on the importance of competency standards as framework for defining a profession that determines work outcomes. The present condition on the low quality of kleders in the Camara Nusantara Ship was related to the level of education and background, recruitment system and less training on competence level. Triyonggo et al. (2015) stated that formal education institutions in Indonesia have not yet implemented a competency-based curriculum so that graduates are not ready to face challenges in the world of work. These conditions indicate that the government and related institutions such as PT. PELNI as a ship operator as well as an educational institution must work hand-in-hand through a collaborative activities in curriculum and training to provide skilled persons with competencies to work as kleder on livestock ship. The existence of certification for Human Resources who are workin on livestock vessels should have working guarantee especially professional stockman officer or kleder.

The availability of SKKNI for kleders on livestock vessels is expected to provide tools for formulating appropriate training programs and activities for improving kleders competence, who are the most responsible workers for cattle management on board. All stakeholders such as governments, ship operators, higher education institutions and other related organizations involved in the whole supply chain process, need to work hand in hand and establish a close collaboration to produce a quality working standards for kleder by considering all elements resulted from this finding.

\section{CONCLUSION}

It can be concluded that main strategies to improve kleder competence was based on Factor, Actor, and Goals elemen. Human resource improvement become the main important elemen in all strategies provided, and ship operator knowledge and skill improvement in Actor elemen need also to be considered. The preparation of Indonesia National work Compentency Standard is essensial to provide kleders with certificate and appropriate skill which is compatible with the national standard.

\section{ACKNOWLEDGEMENT}

High appreciation to all members of Department of Animal Production and Technology, including the technicians and lecturers for their continuous guidance, help and support given throughout the project. Special thanks are due to Animal Logistic Indonesia and Netherland (ALIN), for the financial support in the project to make this study was successfully completed. 


\section{REFERENCES}

Arikunto, S. 2006. Metode Penelitian Kualitatif. Bumi Aksara, Jakarta.

Ardiana, I. D. K. R, I. A. Brahmayanti, \& Subaedi. 2010. Kompetensi SDM UKM dan pengaruhnya terhadap kinerja UKM Surabaya. J. Manajemen dan Kewirausahaan 12(1): 42-55.

Albayrak, E., \& Y. C. Erensal. 2004. Using analytic hierarchy process (AHP) to improve human performance: An application of multiple criteria decision making problem. Journal of Intelligent Manufacturing 15: $491-503$.

Al-Harbi, \& K. M. Al-Subhi. 2001. Application of the AHP in project management. International Journal of Project Management 19: 19-27.

Ananda, M. S., A. Sukmawati, M. Syamsun, \& N. A. Ali. 2016. Pengembangan Model Peningkatan Kompetensi Pekerja Domestik Indonesia di Malaysia. Jurnal Manajemen Teknologi 15: 262-278.

Australian Standard of Export of the Livestock. 2008. Training Gap Analysis. Meat \& Livestock Australia, Sydney.

DAFF. 2011. Australian Standards for the Export of Livestock and Australian Position Statement on the Export of Livestock. Department of Agriculture, Fisheries and Forestry, Canberra.

Direktorat Jenderal Peternakan dan Kesehatan Hewan. 2017. Pedoman Pelaksanaan Tata Niaga Ternak Melalui Transportasi Laut tahun 2017. Direktorat Jenderal Peternakan dan Kesehatan Hewan, Jakarta.

Bergenhenegouwen, G., H. Horn, \& E. Mooijman. 1996. Competence development- a challenge for HRM professionals: core competences of organisations as guidelines for the development of employees. Journal of European Industrial Training 29: 29-35.

Hafeez, K., \& E. Essmail. 2007. Evaluating organisation core competences and associated personal competencies using analytical hierarchy process. Management Research News, 30: 530-547.

Haryana, A., \& Y. Nuryati. 2016. Peran kapal ternak dalam memperlancar distribusi dan menekan biaya logistik daging sapi dari sentra produsen ke sentra konsumen di Indonesia. Jurnal Pusdiklat Perdagangan 2: 78 - 85.

Hermsworth, P. H., \& G. J. Coleman. 2014. HumanLivestock Interaction Second Edition: The stockperson and the Productvity and Welfare of Intersvely Farmed Animals. CAB Internayional, Chippenham.
Ilham, N., \& Y. Yusdja. 2017. Sistem transportasi perdagangan ternak sapi dan implikasi kebijakan di Indonesia. Analisis Kebijakan Pertanian 2(1): 37 - 53.

Jurnal Maritim. 2019. Empat Tahun Tol Laut, PELNI Angkut 40.310 Ekor Sapi. Jurnal Maritim Ed. November 2019.

Matutina. 2001. Manajemen Sumber daya Manusia cetakan kedua. Jakarta (ID): Gramedia.

Ministry of Transportation. 2016. Peraturan Menteri Perhubungan Nomor PM 74 Tahun 2016 tentang Perubahan Atas Peraturan Menteri Perhubungan Nomor PM 93 Tahun 2013 Tentang Penyelenggaraan Dan Pengusahaan Angkutan Laut. Menteri perhubungan Republik Indonesia, Jakarta.

Saaty, T. L. 1991. Pengambilan Keputusan: Bagi Para Pemimpin (Setiono L, Trans) [Decision Making For Leaders].; Peniwati L. (ed). PT Dharma Aksara Perkasa, Jakarta.

Schipp, M. 2013. The welfare of livestock transported by sea: Australia's experience. The Veterinary Journal 196: $282-283$.

Sudarwati, H., \& T. Susilawati. 2013. Pemanfaatan Sumberdaya Pakan Lokal Melalui Integrasi Ternak Sapi Potong dengan Usaha Tani. Jurnal Ternak Tropika 14(2).

Talithania, D., Salundik, \& A. Yani. 2020. Kualitas Udara Selama Perjalanan di Kapal Motor Camara Nusantara 3 [Air Quality During Journey Inter-island On Camara Nusantara 3 Ship]. Jurnal Ilmu Produksi dan Teknologi Hasil Peternakan 8(2): 61-66.

Triyonggo, Y., M. S. Maarif, A. Sukmawati, \& L. M. Baga. 2015. Analisis Situasional Kompetensi Praktisi Sumber Daya Manusia Indonesia Menghadapi MEA. Jurnal Manajemen Teknologi 14(1): 100-112.

Wellard. 2018. Wellard Annual Report 2018. Wellard Ltd, Perth.

Winarso, B. 2017. Peran Angkutan Laut dalam Meningkatkan Distribusi Ternak Sapi Potong dari Daerah Produsen ke Wilayah Konsumen. Jurnal Penelitian Pertanian Terapan 14(2): 83 - 96.

Yanuartono, H. Purnamaningsih, S. Indarjulianto, \& A. Nururrozi. 2017. Potensi jerami sebagai pakan ternak ruminansia. Jurnal Ilmu-Ilmu Peternakan 27(1): 40-62.

Zulhijariyanto, A. M. Fuah, L. Cyrilla, \& Y. Triyonggo. 2019. Job Design of the Kleder in Cattle Distribution Chain on the Camara Nusantara Cattle Ship. Sriwijaya Kournal Of Environment 4(3): 117-122. 